\title{
J.A. Symonds on Socialism and the Crisis of Sexuality in fin-de-siècle Britain ${ }^{1}$
}

Professor Colin Tyler, FRHistS, University of Hull, UK

\begin{abstract}
This article analyses the theory of sexuality, personality and politics developed by the literary critic John Addington Symonds (1840-93). Sections 1 and 2 introduce Symonds' changing reputation as a modernist theorist of "sexual inversion" (homosexuality). Section 3 examines his conceptualisation of the processes whereby an individual can sublimate sexual urges to create a harmonious and unalienated personality which acknowledges the need to combine transgressive self-expression with social convention. Section 4 demonstrates how this theory led Symonds to endorse an eroticised form of democratic socialism, while section 5 explores the culmination of Symonds' thought in a form of pantheistic idealism.
\end{abstract}

\section{Introduction}

It was in February 1877 while in a London brothel with a male prostitute, that the literary critic and poet John Addington Symonds (1840-93) experienced a profound revelation. The postcoital Symonds wondered whether the erotic encounter he had just had with "the strapping young solider with his frank eyes and pleasant smile" offered a path to resolving the profound existential, social and spiritual crises that many people felt were engulfing British society. ${ }^{2}$ In an age shortly before Oscar Wilde (1854-1900) and Sigmund Freud (1856-1939) and long before Herbert Marcuse's Eros and Civilisation (1955), Symonds returned time and again to the question of how to achieve an eroticised mode of fraternity. ${ }^{3}$ His goal was always the same: to address the crisis of sexuality in fin-de-siècle Britain and the other advanced countries of the world in a manner that echoed the response he detected in the American poet Walt Whitman. He encapsulated this goal in a slightly different context, towards the end of his A Problem of Modern Ethics (1891): "Eliminating classical associations of corruption, ignoring the perplexed questions of a guilty passion doomed by law and popular antipathy to failure, [Whitman] begins anew with sound and primitive humanity. There he discovers 'a superb friendship, exalté, previously unknown."'4 From such a basis, Symonds sought to counter "the morbid symptoms of

\footnotetext{
${ }^{1}$ I am pleased to thank the following for their comments on drafts of this article: Jim Connelly, Adonis Hatzistavrou, Sameera Khalfey, Catherine Marshall, Stephané Guy, Peter Nicholson, Noel O’Sullivan, Amber Regis, Jean-Paul Rosaye, Kathleen Tipler, Pip Tyler and Tony Ward. The usual disclaimer applies.

${ }^{2}$ J.A. SYMONDS, Memoirs, ed. P. Grosskurth, London: Hutchison, 1984, pp.253, 254.

${ }^{3}$ H. MARCUSE, Eros and Civilisation: A philosophical inquiry into Freud, London: Arc, 1987 [1955].

${ }^{4}$ J.A. SYMONDS, A Problem in Modern Ethics: being an enquiry into the phenomenon of sexual inversion, addressed especially to medical psychologists and jurists, London: privately printed, 1891, p.122.
} 
suppression, of hypertrophy, of ignorant misregulation, in a genuine emotion capable of being raised to good by sympathetic treatment." ${ }^{5}$

Despite the recognition among literary historians of Symonds as an important and prescient figure, he is not studied by historians of socialism. One possibly very significant reason for this neglect is also deeply ironic. In spite of the marginalisation and in many cases great hostility faced by radical women and radical workers, these two groups could agitate far more openly in the late-Victorian period than sexual reformers could ever dream of doing. The irony is then that the neglect of advocates of sexual liberation by current historians of radical politics reflects and perpetuates the silencing of a group that was profoundly marginalised in Britain for much of the twentieth-century and obviously continues to be so in a great many other parts of the world. This article explores the key features of Symonds' position in the following way. Section two sketches the mode of modernity in which Symonds lived, his standing as an intellectual and the current interest in his thought among literary and queer historians. Section three analyses Symonds' conceptualisation of the process of the sublimation of deviant desires through the critical appropriation of one's cultural heritage. Section four explores Symonds' reflections on the social dimensions of his preferred form of socialism. Section five uncovers the pantheistic mysticism that underpinned Symonds' thought. It is concluded that Symonds' clandestine works reveal him to have been an ambiguous figure who thought of himself as writing in a time of profound crisis and opportunity. ${ }^{6}$ The article establishes that Symonds' paradoxical effort to combine transgressive self-expression with social integration was conditioned heavily by his place in the sexual and social crises of fin-desiècle Britain. It is this fluid and crisis-ridden context which helps to explain the peculiar combination of social heresy and community integration, personal sublimation and social reform which was evident throughout his social and political thought.

\section{Symonds' modernity and his reputation}

Symonds lived through a profoundly significant period of European history. It saw the emergence of a particularly acute form of modernity. As Berman has noted, "To be modern is to live a life of paradox and contradiction", with the institutions of centralised administration increasingly tending to dwarf communities and individuals who, nevertheless, "fight to change their world and make it their own. It is to be both revolutionary and conservative...To be modern is to find ourselves in an environment which promises us adventure, power, joy, growth, transformation of ourselves and the world", while also threatening to destroy the

\footnotetext{
${ }^{5}$ SYMONDS, Modern Ethics, p.122.
} 
foundations of our lives. ${ }^{7}$ While the heat of the mid-Victorian "crisis of faith" had dissipated somewhat by the 1890 s, the late-Victorian era remained a time of rapid change and uncertainty. In Britain, the Reform Acts of 1867 and 1883 enfranchised working men and male peasants which in turn did much to empower them politically, while the rise of the New Trade Unionism in the 1880s and 1890s helped to empower many working men economically. The era saw the 1882 Married Women's Property Act, the gradual extension of higher educational opportunities to women, the development of the settlement movements and the new legal requirement that all adults ensure that their children received elementary education, as well as an increasing sense of social mission among the churches, together with many other laws and social movements. Other changes occurred. Punishments for certain crimes were lessened during this period. For example, sodomy carried the death penalty until 1861, when the penalty was amended to long periods of imprisonment, flogging and hard labour. Each of these changes represented clear challenges to the dominance of middle and upper-class men. Not all of these changes signalled a significant democratisation or liberalisation of attitudes however. For example, the sodomy law was changed primarily because most juries would rather acquit rather effectively sentence the accused to death, whereas they would convict for a less severe but still very harsh punishment. Nevertheless, it remains the case that, on balance, the 1880s and 1890s were decades of great and rapid change in many European countries, and not least Britain, and these changes provoked a sense of crisis in many core areas of life: economic, social, political and personal.

This fin-de-siècle modernity framed Symonds' life. Even though he was largely forgotten for most the twentieth-century, Symonds was a prominent figure in the European literary world of the 1880s and 1890s. Currently, there is something of a revival of interest among historians, yet Symonds is remembered primarily not for his public writings, but rather for his privatelycirculated works on sexuality and especially his writings on sexual inversion (now called homosexuality) and his self-embargoed autobiography. ${ }^{8}$ This clandestine influence was significant. He was a close friend and confidant of the seminal utilitarian philosopher Henry Sidgwick, who was himself bisexual. ${ }^{9}$ Symonds was a significant influence on the romantic socialist and outspoken advocate of sexual freedom and free love, Edward Carpenter. With the

\footnotetext{
${ }^{6}$ H.J. BOOTH, "John Addington Symonds, Venice and the Gaze", English Studies, vol.94, no 2, 2013, pp.17172.

${ }^{7}$ M. BERMAN, All That is Solid Melts into Air: The experience of modernity, new edition, London \& New York: Verso, 2010, pp.13, 15.

${ }^{8}$ S. BRADY, Masculinity and Male Homosexuality in Britain, 1861-1913, Houndsmill: Palgrave MacMillan, 2005, p. 184.

${ }^{9}$ For example, Symonds' relationship with Sidgwick occupies a quarter of B. SCHULTZ, Henry Sidgwick: The Eye of the Universe - A biography, Cambridge: Cambridge University Press, 2004.
} 
sexologist Havelock Ellis, Symonds co-authored a pioneering book in sexual studies, Sexual Inversion.

\section{Culture and the crisis of the sexual self}

The contemporary cultural and queer scholarship on Symonds' historical significance has drawn almost exclusively on his literary and biographical writings. The analysis of his theory of personality and culture developed in this section takes a rather different approach, by focusing on Symonds' more philosophical texts, which it uses as evidence from which to reconstruct his world-view and reformism. This approach extends our understanding of Symonds in important ways. Despite the dearth of published research into Symonds' writings by historians of philosophy and social and political thought, an appreciation of Symonds as a "transitional figure" between Victorian respectability and modernism suggests themes that should be of interest to intellectual historians and especially historians of social and political thought. One of the most important themes is Symonds' advocacy of a liberal form of socialism and democratic communal life. To develop this case, the following analysis focuses on Symonds' conception of the self and his use of idealist and romantic themes to sketch a social theory that enabled people such as himself to transform their "sexually-inverted" urges into socially-beneficial attitudes and actions.

Symonds sought to develop a theory of the good society which respected individual subjectivity. He wished to accommodate what were in late-nineteenth century Britain sociallydeviant subjectivities within an organic harmony of personalities that was particularised within a stable system of cultural norms and practices. In this sense, Symonds did not seek to develop a socially-distinct identity for those with unconventional proclivities; rather, he wished them to enjoy the integrated existence of sexually-inverted yet fully-accepted, equal and active citizens. He criticised Hippolyte Taine for failing to "make sufficient allowances for the resistance which the individual offers to his milieu, for the emergence in him of specific strains of atavism, and for the peculiar phenomena of mental hybrids." 10

Symonds developed his position in his 1893 collection In The Key of Blue, especially in the essay 'Culture: Its meaning and its uses'. This piece was Symonds' most complete statement of his theory of "self-effectuation" and its relationship to sublimation of sexually-inverted urges. ${ }^{11}$ In this essay, Symonds characterised "culture" as "the raising of previously educated

\footnotetext{
${ }^{10}$ J.A. SYMONDS, "The Philosophy of Evolution", in SYMONDS, Essays Speculative and Suggestive, third edition, London: Smith, Elder, 1907 [1890], p.7.

${ }^{11}$ J.A. SYMONDS, "Culture: Its meanings and its uses", in SYMONDS, In The Key of Blue and other prose essays, London: Elkin Mathews, 1896 [1893], pp. 195-216; see also Brady, Masculinity, pp.160-61.
} 
intellectual faculties to their highest potency by means of the conscious efforts of their possessors." 12 He emphasised his restriction of culture to "intellectual faculties", and explicitly excluded "morals and athletics'.13 Where "education" was something done to the individual by another person (a teacher), the alternative process of raising an individual's level of culture was a project which could be carried out only by that individual him or herself: "Education educes or draws forth faculties. Culture improves, refines, and enlarges them, when they have been brought out."14 This was the process of self-effectuation. It was driven by the individual themselves, through his efforts "to arrive at his true self, to perfect the rudiments supplied by Nature on the line for which he is best qualified, and by so doing to arrive at independence what the Germans call Selbstständigkeit."15 In this way, the truly cultured individual could develop his own "character", "personality", "energy" and "independence', something that enabled him to follow his intellectual path rather than adhering passively to the fashions of "cliques and school[s]", "prejudices" and "fashions". 16 Moreover, this search was intrinsically practical or, as Symonds put it, the search engaged with "the great world" rather than being restricted to the mere "silence of the study". ${ }^{17}$ By living in this way, the cultured individual developed a number of "mental force[s]" which Symonds equated to a number of selves organised so as to enable him to live "in the large sphere of universal and enduring ideas." 18 This was not to say that every individual progressed in the same manner. Geniuses were driven to achieve culture "by an act of instinct", while talented individuals needed to draw on the greatest achievements of humanity. ${ }^{19}$ Nevertheless, everyone formed part of a single overarching project of personal and collective enrichment, which Symonds characterised in the following way.

"Culture is self-tillage, the ploughing and the harrowing of self by use of what the ages have transmitted to us from the work of gifted minds. It is the appropriation of the heritage bequeathed from previous generations to the needs and cravings of the individual in his emancipation from 'that which binds us all, the common.' It is the method of self-exercise which enables a man, by entering into communion with the greatest intellects of past and present generations, by assimilating the leading ideas of the World Spirit, to make himself, according to his personal capacity, an efficient worker, if not a creator, in the symphony for ever woven out of human souls." 20

\footnotetext{
${ }^{12}$ SYMONDS, "Culture”, p.197; see ibid., p.199.

${ }^{13}$ SYMONDS, "Culture", p.197; see ibid., p.199.

${ }^{14}$ SYMONDS, "Culture", p.197.

${ }^{15}$ SYMONDS, "Culture", pp.197-98.

${ }^{16}$ SYMONDS, "Culture", p.209.

${ }^{17}$ SYMONDS, "Culture", p.198.

${ }^{18}$ SYMONDS, "Culture", p.198.

${ }^{19}$ SYMONDS, "Culture", p.199.

${ }^{20}$ SYMONDS, "Culture", pp.200-01.
} 
In line with his philosophy of evolution (analysed below), Symonds believed that, when properly pursued, "Culture prepares us to acquiesce in this state of things as part of the universal order." ${ }^{21}$ Nevertheless, this order was a harmony of interconnecting parts, rather than a blank undifferentiated unity. Hence, Symonds sought to use a diverse cultural life to combine a respect for individual subjectivity with vibrant collective harmony. For this reason, he argued that

"Society would reach something like perfection if each individual succeeded in self-effectuation, fulfilling the law of his own nature, and being distinguished from his neighbours by some marked quality, some special accomplishment. The concord of divers instruments constitutes the music of a symphony. The blending of distinct personalities creates the finest mental and moral harmony." 22

While this passage has strong echoes of Symonds' friend and brother-in-law T.H. Green's conception of an enriching community, he developed his position by alluding to J.S. Mill: "we suffer too much from the tyranny of majorities, the oppression of custom, the gregarious instinct of commonplace and timid persons", he wrote. "[T]rue culture tends to the differentiation of individualities, by enabling people to find out what they are made for, what they can do best, what their deepest self requires for its accomplishment."23 Moreover and as Green, Mill and Symonds emphasised, progress entailed conflict. For this reason, social progress occurred best in tolerant societies where every individual could become cultured in his ways. ${ }^{24}$ When that tolerance was absent, Symonds insisted, "mental alienation sets in", and one's "character" tended to be "degraded'.25

Symonds argued at length that cultural development drew on past achievements in art and literature and the other humanities to develop the individual. This was significant because, as Brady has claimed, by challenging French and German scientific approaches in his treatise $A$ Problem in Modern Ethics, Symonds presented "the only contemporary humanist critique of Continental inversion theorisation." 26 Yet, Symonds did not see culture as a free-standing motor of identity-formation. In fact, he argued, culture could build only on the individual's innate

\footnotetext{
${ }^{21}$ SYMONDS, "Culture”, pp 215-16.

22 SYMONDS, "Culture", p.214.

${ }^{23}$ SYMONDS, "Culture", p.214; T.H. GREEN, Prolegomena to Ethics, Oxford, Clarendon, 1883, sections 18091; J.S. MILL, On Liberty, ed. M.B. Mathias, New York: Pearson, 2007, chapter 1.

${ }^{24}$ SYMONDS, “Culture”, p.215; SYMONDS, "Evolution", p.22.

${ }^{25}$ SYMONDS quoted in BRADY, Masculinity, pp.190, 170.

${ }^{26}$ BRADY, Masculine, p.188.
} 
capacities and predilections: "It has no power to stand in the place of Nature, and to endow a human being with new faculties in a chosen line of work, with a certain spirit of freedom, with a certain breadth of understanding." 27 One could not impose culture on another person, neither could one make someone truly cultured in a way that ran counter to their innate if initially undeveloped capacities and tendencies. What Gay has written of the composer August Strindberg applied just as much to Symonds: "From his vantage point, he argued that human nature is not cast in bronze, but open to the most disparate pressures, some from social demands and others, less easy to trace, from inner urges." 28 Personal, social and even cultural crises were motors of self-effectuation.

The first wave of historians of sexuality writing in the 1970s saw Symonds as little more than a self-loathing bourgeois apologist, usually citing the outwardly respectable life that he lived with his wife and four daughters. ${ }^{29}$ Indeed, in his Memoirs Symonds acknowledged that as a younger man he was ambivalent regarding sex: "The attractions of a dimly divine almost mystic sensuality persisted in my nature, side by side with a marked repugnance to lust in action, throughout my childhood and boyhood down to an advanced stage of manhood."30 From 1859 until 1862, he had close relationship with a youth three years his junior: "Only twice he kissed him", yet "those two kisses were the most perfect joys he ever felt." 31 Partly reflecting the "marked repugnance to lust in action" that he felt at other times, Symonds had made great efforts to deny his true feelings, not least by trying to convince himself of some sexual attraction to women even going so far as to marry in $1864 .{ }^{32}$ Moreover, in 1889 he acknowledged the dangers of teaching the history of Greek love to undergraduates in a long letter to Jowett, where he wrote: "Such passion is innate in some persons no less than the ordinary sexual appetite is innate in the majority. With the nobler of such predetermined temperaments the passion seeks a spiritual or ideal transfiguration." 33

Yet, throughout Symonds recognised that his self-repression as a relatively young man caused him great anguish, and eventually very serious medical problems including "insomnia, obscure cerebral discomfort, stammering, chronic conjunctivitis, inability to concentrate his

\footnotetext{
${ }^{27}$ SYMONDS, "Culture", p.204.

${ }^{28}$ P. GAY, Modernism: The Lure of Heresy From Baudelaire to Beckett and Beyond, London: Vintage, 2009, p.345.

${ }^{29}$ See BRADY, Masculinity, pp.159-60.

${ }^{30}$ SYMONDS, Memoirs, p.62.

${ }^{31}$ H. ELLIS, "Appendix One: Case XVII: in Sexual Inversion by Havelock Ellis (1897)", in SYMONDS, Memoir, p.286.

${ }^{32}$ SYMONDS, Memoirs, pp.143-45.

${ }^{33}$ Letter from Symonds to B. Jowett, 1 February 1889, in SYMONDS, Letters, vol.3, p.346.
} 
attention, and dejection", leading his general health to collapse. ${ }^{34}$ As he wrote in his 1889 letter to Jowett, "The contest of the Soul is terrible, and victory, if gained, is only won at the cost of struggle which thwarts and embitters." 35 Crucially, Symonds laid the responsibility for this struggle with Britain's profoundly hostile social conventions, rather than with his sexual inversion. Yet, at least in his twenties Symonds believed that limits should be placed on sexual practices. One might take this belief as indicating Symonds' self-hatred and his desire to suppress his sexually-deviant urges. Consider Symonds' intervention in an affair that occurred in the late 1850s between Dr C.J. Vaughan who was Headmaster of Harrow School (Symonds's alma mater) and Alfred Pretor, a pupil at the school. ${ }^{36}$ Symonds told his father of the illicit relationship, and his father blackmailed Vaughan into resigning as headmaster and never holding an ecclesiastical position for the remainder of Symonds' father's life. The younger Symonds was also dismayed by Vaughan's behaviour, even if it is not clear that he had intended his father to act as he did. It is true that Symonds reaction seems more severe due to a significant element of self-identification: "If he [Vaughan] had sinned, it had been by yielding to passions which had already mastered me." ${ }^{37}$ Yet, what shocked Symonds was not that Vaughan had committed sexual acts with another male, but that he had done so with a pupil in his charge and had done so while holding high office in one of the most influential anti-inversion organisations in the country: the Church of England.

Symonds did insist on the need not to trample over conventional ideas regarding "religion, domesticity, reverence, [and] discipline". ${ }^{38}$ Yet, later events indicate a more liberal view from that of a Symonds who felt a "marked repugnance to lust in action". Symonds records that his own sexually-induced health problems were relieved only once he became sexually active with men, something that he began to do tentatively around 1871, following the death of his father, becoming fully active by 1877.39 In that year, he moved his family from Britain to the far-more liberal sexual atmosphere of Davos in Switzerland. In addition to having affairs in Davos, he could travel to Venice for liaisons with gondoliers and other young men. Obviously, such behaviour might still mean that Symonds was a hypocrite or a self-loathing bourgeois apologist. After all, in The Methods of Ethics Symonds' friend and fellow sufferer Sidgwick advocated the enforcement of a restrictive conventional morality on the vast majority of the population (whom Sidgwick called "the vulgar") at the same time as defending an "esoteric" morality for "a class of persons defined by exceptional qualities of intellect, temperament, or

\footnotetext{
${ }^{34}$ ELLIS, “Case XVII", p.287.

${ }^{35}$ Letter from Symonds to B. Jowett, 1 February 1889, in SYMONDS, Letters, vol.3, p.346.

${ }^{36}$ SYMONDS, Memoirs, p. 115.

${ }^{37}$ SYMONDS, Memoirs, p.112.

${ }^{38}$ Letter from Symonds to C.B. Green, 3 November 1866, in SYMONDS, Letters, vol.3, p.177.
} 
character". ${ }^{40}$ Yet, Symonds' position was rather less elitist than the one espoused by Sidgwick, and probably rather less objectionable to queer theorists. Symonds' case-notes (taken sometime between 1890 and his death in 1893) ended with the unequivocal endorsement of his moral innocence: "He has no moral sense whatever of doing wrong ... He feels the intolerable injustice of his social position, and considers the criminal codes of modern nations, in so far as they touch his case, to be iniquitous." 41 Symonds placed special significance on the experience he enjoyed with the solider in the male brothel in February 1877. "The experience had a powerful effect upon my life", he wrote in his Memoir.

"I learned from it ... that the physical appetite of one male for another may be made the foundation of a solid friendship, when the man drawn by passion exhibits a proper respect for the man who draws. I also seemed to perceive that, within the sphere of the male brothel, even in that lawless godless place, permanent human relations - affections, reciprocal toleration, decencies of conduct, asking and yielding, concession and abstention - find their natural sphere...[Repeating the experience on many other occasions, I found that such relationships] never seem[ed] to outrage any purely natural sentiments, but only colliding with the sense of law and the instincts of convention. ... [The soldier was] supremely beautiful in my eyes, so attractive to my senses. He was a very nice fellow, as it turned out: comradely and natural... For him at all events it involved nothing unusual, nothing shameful; ... [I] sat and smoked and talked with him, and felt, at the end of the whole transaction, that some at least of the deepest moral problems might be solved by fraternity." 42

From that time onwards, Symonds sought a society that facilitated the expression of its citizens' deepest urges; he sought a society in which, as he put it in a different context, his "dreams [of eroticised camaraderie] were self-created, self-sustained, enshrined in self, fed from self." 43 Yet, even as he sat in the room Symonds recognised the imperfection of a sense of fraternity that grew up in a brothel, between a rich middle-aged man of literary standing and relatively poor young soldier. The brothel itself was a "lawless, godless place", the power-relationship decidedly unequal, and the commercial basis of their transaction corrupted the fraternity of their sexually-enlivened relationship. ${ }^{44}$ Symonds wondered about the less pleasant encounters the soldier was very likely to have suffered with other clients, "and thinking how mean and base

\footnotetext{
${ }^{39}$ SYMONDS, Memoirs, pp.233-35; ELLIS, “Case XVII", p.287.

${ }^{40}$ H. SIDGWICK, The Method of Ethics, seventh edition, London: MacMillan, 1907, pp.489-90.

${ }^{41}$ ELLIS, "Case XVII", p.288.

${ }^{42}$ SYMONDS, Memoir, p.254.

${ }^{43}$ SYMONDS, Memoir, p.144, quoting his August 1863 diary.

${ }^{44}$ SYMONDS, Memoir, pp.254-55.
} 
any comradeship must be, built upon such foundations." 45 The brothel "raised disgust, and I left it shaking the dust and degradation of the locality off my feet." 46 Yet, from this soldier, Symonds "learned that natural male beings in the world at large were capable of corresponding to my appreciation of them. A dangerous lesson, perhaps." 47 In this way, Symonds was immediately sensitive to the fact that social environment played a central role in the creation of healthy fraternal relationships between men. It is no surprise then that, in response to the feeling of ease with his own sexual inversion that he had come to enjoy by the early 1890 s, and combined with his sense of injustice at the social repression of that inversion, Symonds campaigned clandestinely for a society in which every individual was able to incorporate their sexual urges into their personal identity, to act on those incorporated urges while respecting the tolerant forms of "religion, domesticity, reverence, [and] discipline" which bind their community together. ${ }^{48}$ This new society would begin to arise, Symonds observed in an 1892 letter to Edward Carpenter, when they had "force[d] people to see that the passions in question have their justification in nature." 49 At its heart would lie "a new chivalry, i.e. a second elevated form of human love". 50

Symonds championed his culturally-informed approach to personal identity against the scientific approaches that dominated the Continent. ${ }^{51}$ Indeed, during this time many French and German psychologists such as Paul Moreau, B. Tarnowski, Richard von Krafft-Ebing and Karl Ulrich adopted scientific methods and popularised the view that sexual inversion was a perversion resulting from the individual's failure to relate appropriately to his true heterosexuality, a position that was popularised shortly afterwards by Sigmund Freud. As noted above, Symonds saw things differently however. Certainly, he tended to characterise sexual inversion as "abnormal" and heterosexuality "normal", yet he rejected strongly those who described sexual inversion as a "neurotic disorder inherited or acquired".52 Symonds regarded sexual inversion as simultaneously both abnormal and natural. It was a profound "mystery of sex" that constituted one of "the variety of type exhibited by nature."53 He encapsulated his position thus.

\footnotetext{
${ }^{45}$ SYMONDS, Memoir, p.254.

${ }^{46}$ SYMONDS, Memoir, p. 255.

${ }^{47}$ SYMONDS, Memoir, p. 255.

${ }^{48}$ Letter from Symonds to C.B. Green, 3 November 1866, in SYMONDS, Letters, vol.3, p.177.

${ }^{49}$ Letter from Symonds to E. Carpenter, 29 December 1892, in SYMONDS, Letters, vol.3, p.799.

${ }^{50}$ Letter from Symonds to Carpenter, 29 December 1892, in SYMONDS, Letters, vol.3, p.799.

${ }^{51}$ See BRADY, Masculinity, pp.187-88.

${ }^{52}$ SYMONDS, Memoirs, p.64.

${ }^{53}$ SYMONDS, Memoirs, p.65.
} 
"Character might be described as the product of inborn proclivities and external circumstance. If we regard temperament as one factor and circumstance as another, we must also bear in mind that temperament takes and rejects, assimilates and discards, the elements of nutrition afforded by circumstance according to an instinct of selection. Boys of more normal sexuality [than the adolescent Symonds] might have preferred the 'Rape of Lucrece' to 'Venus and Adonis'. Or, in the latter, they might have felt the attraction of the female - condemning Adonis for a simpleton, and wishing themselves for ten minutes in his place." 54

One's reaction to circumstance was conditioned by one's particular "inborn proclivities". This was significant because, contrary to the established view of French and German psychologists, Symonds believed that individuals were born sexually-inverted or heterosexual (or somewhere in-between), rather than deviating from a natural heterosexuality due to harmful experiences after birth. It was because he believed that true culture enabled those proclivities to develop fully and in healthy ways that Symonds became a keen advocate both of greater openness regarding sexual inversion and of its social and legal acceptance. As he observed towards the end of his essay on "Culture": "true culture tends to the differentiation of individualities, by enabling people to find out what they are made for, what they can do best, what their deepest self requires for its accomplishment." 55 As has been noted already, for Symonds, such a culture relied on a certain tolerance of difference, which extended just as much to sexual inverts as it did to those with "normal" proclivities.

In short, Symonds wished the individual to possess a complex personality which integrated all aspects of themselves, including those that were socially-unacceptable and, where present, their sexual inversion. He argued that such integration would be possible only to the extent that one lived in a tolerant society. Counterfactually, he rejected the creation of a distinct "camp" identity of the type came to dominate homosexual politics following the imprisonment of Oscar Wilde some years after Symonds' death in 1893. Rather than being a straightforward example of self-loathing Victorian hypocrisy, Symonds' attitude to sexuality is increasingly popular in contemporary queer politics. C.J. Dean has noted that,

'Most inquirers can agree that the link between sexuality and the self is historically contingent and its meaning culturally invested; that sexual identity never exhausts the self and yet always

\footnotetext{
${ }^{54}$ SYMONDS, Memoirs, p.63; compare with ELLIS, "Case XVII”, p.285.

55 SYMONDS, "Culture”, p.214.
} 
constrains it, that sexuality may express a free or private self and yet is never, in spite of all our illusions, simply free or private." 56

As Sean Brady has noted, increasingly it is being recognised that innate desires and social forms stand in reciprocal relationships that require mutual negotiation. This was precisely Symonds' position. ${ }^{57}$ As he put it: "We are, all of us, composite beings, made up, heaven knows how out of the compromises we have effected between our impulses and instincts and the social laws which gird us around." 58

\section{Symonds' democratic socialism}

In a letter of November 1886 to his sister Charlotte, Symonds remarked that: "Personally I may say that he [Green] inducted me into the philosophy of democracy \& socialism - not in any sentimental or visionary or reactionary way - but on the grounds on wh [ich] both democracy \& socialism are active factors in modern politics." ${ }^{\prime 2}$ He explained this influence more fully towards the end of the letter.

“[I]t is [Green's] distinction to have early recognized that Democracy (implying political \& social advantages on equal terms) \& Socialism (implying an equitable distribution of wealth) are the cardinal questions of the modern world; \& while recognizing this, to have been led astray by no glittering theory or enthusiasm for impossible Utopia, but to have steadily considered how \& at what points the needful evolution might be constituted (i.e. without rupture or reaction) \& beneficially (i.e. with regard for those ground-elements of human nature wh[ich] are religion, domesticity, reverence, discipline, etc) effected."60

Yet, there was a new element to Symonds' theory of democratic community. He became conscious of this other element during his visit to the male brothel in February 1877: the link between sublimated sexual inversion and fraternity. Symonds explored this link frequently in his writings. For example, in his essay "The Dantesque and Platonic Ideals of Love", Symonds argued that two of the greatest geniuses were inspired by two very different types of love: one heterosexual, the other sexually-inverted. Yet, very significantly he argued that while "amorous enthusiasm for a particular fellow-creature" of any sex (this person, here and now) could not

\footnotetext{
${ }^{56}$ C.J. DEAN, "Redefining Historical Identities: Sexuality, gender and the self", in L. KRAMER \& S. MAZA (ed.) A Companion to Western Historical Thought, Oxford: Blackwell, 2006, p.369.

${ }^{57}$ BRADY, Masculinity, p. 160 .

${ }^{58}$ Symonds quoted in BRADY, Masculinity, p.170.

${ }^{59}$ Letter from Symonds to C.B. Green, 3 November 1886, in SYMONDS, Letters, vol.3, p.176.

${ }^{60}$ Letter from Symonds to C.B. Green, 3 November 1866, in SYMONDS, Letters, vol.3, p. 177.
} 
sustain higher spiritual effort in the lover, such efforts could be sustained when they infused a whole society. ${ }^{61}$

'What subsists of really vital and precious [qualities] in both ideals [of Plato and Dante] is the emotional root from which they severally sprang: in Greece the love of comrades, binding friends together, spurring them on to heroic action, and to intellectual pursuits in common; in medieval Europe the devotion to the female sex, through manly courtesy, which raised the crudest of male appetites to a higher value."62

Bringing in his theory of culture, Symonds argued that such camaraderie required the individual to be familiar with the high culture of his community. Nevertheless, although Symonds accepted that, when incorrectly understood, the pursuit of culture "encourages the growth of prigs", he rejected absolutely Whitman's claim that culture was inherently elitist: "Given individuals of equal calibre, as many wise men may be found among the artisans and peasants as among reputed savants."63 Every individual had their own capacities and predilections which, under appropriate circumstances could be developed into a cultured life for that individual. Nor did culture properly understood mean snobbery.

"True culture is never in a condescending attitude. It knows that no kind of work, however trivial, ought to be regarded with contempt. People who carve cherry-stones, dance ballets, turn rondeaux, are as much needed as those who till the soil, construct Cabinets, or fabricate new theories of the universe. True culture respects hand-labour upon equal terms with brain-labour, the mechanic with the inventor of machinery, the critic of poetry with the singer of poems, the actor with the playwright." 64

Hence, writing to Carpenter in January 1893, Symonds expressed the hope that "the blending of Social Strata in masculine love" "would do very much to further the advent of the right sort of Socialism", characterised by egalitarianism and co-operation. ${ }^{65}$ In his Memoir Symonds linked his democratic socialism to Whitman's "ideal of comradeship", but in earlier letters he had linked it explicitly to Green's "conception of manly sober citizenship".66 Yet, while Green's conception of "brotherhood" was completely asexual (and indeed ungendered). As has been

\footnotetext{
${ }^{61}$ SYMONDS, "The Dantesque and Platonic Ideals of Love”, in SYMONDS, Key, p.85.

${ }^{62}$ SYMONDS, "Dantesque", pp.84-85.

${ }^{63}$ SYMONDS, "Culture", p.208.

${ }^{64}$ SYMONDS, "Culture", p.214.

${ }^{65}$ Letter from Symonds to E. Carpenter, 21 January 1893, in SYMONDS, Letters, vol.3, p.808. See further P. GROSSKURTH, "Introduction", in SYMONDS, Memoirs, pp.13-28, and J. PEMBLE (ed.) John Addington Symonds: Culture and the demon desire, Basingstoke: MacMillan, 2000.
} 
shown, Symonds characterised his conception of "manliness" in overtly sexual terms. Hence, Symonds invoked the idea of "manly love" as

"a powerful and masculine emotion, in which effeminacy had no part, and which by no means excluded the ordinary [i.e. heterosexual] sexual feelings. Companionship in battle and the chase, in public and in private affairs, was the communion proposed by Achilleian friends - not luxury or the delights which feminine attractions offered." 67

The homoerotic underpinnings of this conception of "manly love" came out more explicitly elsewhere in his Memoirs. Referring to his life in approximately 1889, he confided that,

"I thought it permissible to indulge my sense of plastic beauty in men. ... I thought then that, if I were ever allowed to indulge my instincts, I should be able to remain within [Whitman's] ideal of comradeship. The dominance of this ideal ... contributed greatly to my emotional tendencies. It taught me to apprehend the value of fraternity, and to appreciate the working classes. When I came to live among peasants and republicans in Switzerland, I am certain that I took up passionate relations with men in a more natural and intelligible manner - more rightly and democratically - than I should otherwise have done."68

Even though there is some truth in .Rowbotham's claim that Symonds "viewed socialism through a somewhat long-distance lens", it is evident that he was not "blithely ignorant about how the class system was experienced from the lower rungs".69 As noted, Symonds insisted that one should appreciate that the "capacity for [both] high and sordid action, [was as present] in tillers of soil" as it was in anyone else. ${ }^{70}$ Hence, he argued that the new era in which he lived required a new type of visibly "democratic art", in which "The poet and the artist must repel the temptation to prettify his subject by the addition of masquerade refinement". ${ }^{71}$ Yet, immediately he added that it must not commit the opposite error by tending "to vilify [his subject] by exposing only what is brutal."72 The poet or artist "must be able to recognise that there is as much real beauty in the peasant's husk as in the prince's" ${ }^{73}$ Neither was Symonds' socialism a naïvely peaceful idyll; disagreement and conflict would be a daily

\footnotetext{
${ }^{66}$ Letter from Symonds to C.B. Green, 7 October 1882, in SYMONDS, Letters, vol.2, p.777.

${ }^{67}$ J.A. SYMONDS, A Problem in Greek Ethics being an inquiry into the phenomenon of sexual inversion addressed especially to medical psychologists and jurists, London: Areopagitica Society, 1908, p.3.

${ }^{68}$ SYMONDS, Memoirs, p.191.

${ }^{69}$ S. ROWBOTHAM, Edward Carpenter: A life of liberty and love, London \& New York: Verso, 2008, p.187.

${ }^{70}$ J.A. SYMONDS, "Democratic Art with special reference to Walt Whitman", in SYMONDS, Essays, p.265.

${ }^{71}$ SYMONDS, "Democratic", p.265.

72 SYMONDS, "Democratic", p.265.

73 SYMONDS, "Democratic", p.265.
} 
reality for citizens of his republic, and it should be so. As he observed towards the end of his essay on "Culture": "In the universal symphony strife is no less important than concord."74

This analysis explains Symonds great enthusiasm for .Ellis's 1890 discussion of Whitman's Calamus in the latter's New Spirit. Particularly significant here was the emphasis Ellis placed on Calamus' invocation of love and physical relationship between comrades. Even though Symonds had contributed to projects edited by Ellis since their first contact in 1885, apparently it was not until a letter of 6 May 1890 that Symonds admitted his sexual inversion to him. In the letter, Symonds stated the key question that he had regarding Whitman in the following way: "does Whitman imagine that there is lurking in manly love the stuff of a new spiritual energy, the liberation of which would prove of benefit to society? And if so, is he willing to accept, condone or ignore the physical aspects of the passion?"75

The formulation of the question is interesting in that it recalled Green's claim that "Faculties which social repression and separation prevent from development, take new life from the enlarged co-operation which the recognition of equal claims in all men brings with it."76 Moreover, it anticipated Symonds' theory of culture. He wrote to Whitman on 3 August 1890 linking Whitman's phrase "manly love" directly to the latter's conception of comradeship, and asked whether Whitman "contemplate[d] the possible intrusion of those semi-sexual emotions and actions which do doubt do occur between men?"77 He wondered whether Whitman would clarify his position on sexual inversion (without necessarily clarifying whether he approved of it or not) and to place that answer within his (Whitman's) "philosophy of life".78 Even before he received Whitman's furious denial of inverted undercurrents to his poetry, Symonds's collaborator and admirer Edward Carpenter warned of the naivety - possibly even the rashness - of Symonds's move given the situation for American sexual inverts. ${ }^{79}$ Sure enough, when Whitman replied he protested that Symonds' "questions ... quite daze me", "the possibility of such construction as mentioned is terrible", they are "undreamed and unrecked possibility of morbid inferences". Despite his best efforts Symonds failed to persuade Whitman to "come out'. In fact, Stephen Railton has gone so far as to suggest that "out loud and in public, Whitman denied his sexual inversion. I think that this pattern of denial extended into his psychic life as

\footnotetext{
${ }^{74}$ SYMONDS, “Culture”, p.215.

${ }^{75}$ Letter from Symonds to H. Ellis, 6 May 1890, in SYMONDS, Letters, vol.3, p.459.

${ }^{76}$ GREEN, Prolegomena, section 208.

${ }^{77}$ Letter from Symonds to W. Whitman, 3 August 1890, in SYMONDS, Letters, vol. 3, p.482.

${ }^{78}$ Letter from Symonds to Whitman, 3 August 1890, in SYMONDS, Letters, vol.3, p.482.

${ }^{79}$ See BRADY, Masculinity, p.161.
} 
well: that even to himself he did not want to admit the truth about his sexuality." 80 Symonds was deeply frustrated by such denials and silences. As he observed in a slightly different context:

"Men...who find themselves the slave of a congenital inclination they dare not acknowledge and to which, out of fear, they pay homage in secret, are in greater need of tolerance than mere rakes. Yet they do not get it. They know that, and it makes them desperate; they are secretly at odds with the world and grow increasingly inclined stealthily to yield to unwholesome moods; thus they become ever more cynical, ever more desperate, until finally they lose their honour and self-respect." 81

Symonds goal was to create a society in which a range of sexualities were affirmed (not merely tolerated) as part of a complex set of social relationships that reflected the underlying drives and identities of all citizens. This affirmation was to be accorded openly to sexual inverts as well as heterosexuals, and to women as well as men. ${ }^{82}$ It was precisely because of denials to sociallydeviant urges such as Whitman had given, that, in the final two years of his abruptly-curtailed life, the plight of such men encouraged Symonds to redouble his work with Carpenter and Ellis to encourage greater public debate regarding sexual inversion and hopefully greater public acceptance of it.83 Increasingly, Symonds wrote pamphlets for private circulation, and corresponded with Carpenter often exchanging books, including Carpenter's socialist classic Towards Democracy (1883) and Symonds's 1893 In The Key of Blue. Sadly, his efforts came to an abrupt end when Symonds died suddenly in Rome from pneumonia on 19 April 1893. Carpenter and Ellis continued this work until their deaths in 1929 and 1939 respectively.

\section{Evolution, pantheism and the Cosmic Mind}

Symonds concluded his essay "Culture" on a note that recalled his faith that the conflictual process of human development had something divine at its heart.

"For some reason hidden from our mortal ken the world was meant to be so governed. Phenomenal existence is in a perpetual state of becoming; becoming implies cohesion and dissolution; both processes involve contention. All the soldiers in the armies, if they act with energy, sincerity, disinterested loyalty, serve one Lord and Master."84

\footnotetext{
${ }^{80}$ S. RAILTON, “'As if I Were With You' - The performance of Whitman's poetry”, in E. GREENSPAN (ed.) Cambridge Companion to Walt Whitman, Cambridge: Cambridge University Press, 1995, p.15.

${ }^{81}$ J.A. SYMONDS, "Soldier Love and Related Matter", in SYMONDS, Soldier Love and related matter, trans. \& ed. Andrew Daykyns, Eastbourne: PlanAhead, 2007, p.11.

${ }^{82}$ Letter from Symonds to H. Ellis, 8 May 1890, in SYMONDS, Letters, vol. 3, pp.458-59.

${ }^{83}$ ROWBOTHAM, Carpenter, pp.185-89.

${ }^{84}$ SYMONDS, "Culture", p.216.
} 
Symonds' theory of culture presupposed the theory of spiritual integration and development which he set out primarily in an 1890 essay entitled 'The Philosophy of Evolution'. In the latter as elsewhere, Symonds identified the fundamental principle of his thought as the Goethean maxim that we should aspire "To live resolvedly in the whole, the good, the beautiful." 85 Life in this sense was a process rather than a state of being, something that reflected the inseparability of our individuality from the never-ending process of "Becoming" that pervaded the whole Universe. ${ }^{86}$ That "all things in the universe exist in process" meant that, in reality, even one's firmest beliefs, even the theory of evolution itself, was merely a hypothesis that was being tested constantly by the changing realities thrown up by the worlds of thought and practice. 87 Life was given meaning and significance by the role it played within the never-ending process of evolution, with that process itself seeking to arrive at the truth. For example:

"What is perishable in its [religion's] earthly historical manifestation must be eliminated; and the permanent spirit by which it is animated, the truth it reveals, will be absorbed into the structure of creeds destined successively to superseded it and be superseded." 88

Two elements are notable here in the context of his theory of self-effectuation: his invocation of the creeds gestured towards the collective nature of this process, and his reference to soldiers recalled the role of erotised fraternity. How these two elements intertwined is the subject of this section. Turning to first point, Symonds insisted that self-effectuation resulted not merely from personal subjectivity "but a steady comprehension of the whole. How to grasp the whole, how to reach a point of view from which all manifestations of the human mind should appear as correlated, should fall into their proper places as parts of a complex organism, remained the difficulty." 89 Comprehending the whole did carry the danger of "blunting" the individual's critical judgement, hence it was vital to "make sufficient allowances for the resistance which the individual offers to his milieu, for the emergence in him of specific strains of atavism, and for the peculiar phenomena of mental hybrids." 90 Symonds argued that the fact that individuals could know things about the world implied that each was part of a "Universal Mind". 91 This was a hypothesis towards which each of us was led when thinking clearly: Nature was a continuum that placed humanity at the top of the animal kingdom; and this continuum led up to rational

\footnotetext{
${ }^{85}$ SYMONDS, "Evolution", p.6.

${ }^{86}$ SYMONDS, "Evolution", p.5.

${ }^{87}$ SYMONDS, "Evolution", p.5.

${ }^{88}$ SYMONDS, "Evolution", p.5.

${ }^{89}$ SYMONDS, "Evolution", pp.6-7.

${ }^{90}$ SYMONDS, "Evolution", pp.8, 17.

${ }^{91}$ SYMONDS, "Evolution", p.12.
} 
thought, and appeared to extend beyond humanity to a more powerful and coherent reasoning being. In this way, Symonds derived his Universal Mind in precisely the same way that Green derived his "eternal self-conscious subject of the world". ${ }^{92}$ For both men, to love this eternal subject or Universal Mind required one, in Symonds' words, to "combine the [Christian] conceptions of obedience to supreme Law and of devotion to Humanity, both of which have been spiritualised, sublimed, and rendered positive by the action of thought and experience."93 In slightly less mystical terms, the process's telos was "to create an enthusiasm in which the cosmic emotion shall coalesce with the sense of social duty in which self-abnegating submission to the natural order and self-abnegating service of man shall be regarded as the double function of all human beings in the evolution of the universe."94

While there were echoes of absolute idealists such as Hegel and Green, Symonds placed evolutionary theory at the heart of his theory, where Hegel rejected the theory of evolution and Green held its truth to be unimportant.95 Moreover, Symonds entertained the possible truth of mystic pantheism in ways that Hegel and Green did not: "Paradoxical as his may seem, it is not incredible that the globe on which we live is more conscious of itself than we are of ourselves; and that the cells which compose our corporeal frame are gifted with a separate consciousness of a simpler kind than ours." ${ }^{96}$ Relatedly, he expressed an enthusiastic interest in F.W.H. Myers' work on the "Subliminal Consciousness", in which Myers urged scientists to conduct research into the possibility of non-conscious telepathic communication between individuals and what he believed to be other such paranormal phenomena. ${ }^{97}$ Symonds used his pantheism to shed fresh light on eroticised fraternity and particularly the role of the sexually-inverted "tendencies" of oneself and one's fellows.

"[W]e hold that the individual can only direct, cultivate, and repress tendencies in himself and others. This, however, implies the power of resolution to form good habits and the determination to enforce them by a continued exercise of volition. A man wills to minimise his tendencies towards vice by encouraging his opposite tendencies towards virtue, quite as much as the man who is supposed to change his vicious nature in one moment. The difference is that

\footnotetext{
92 GREEN, Prolegomena, section 99.

93 SYMONDS, "Evolution", p.20.

94 SYMONDS, “Evolution”, p.21.

95 SYMONDS, "Evolution", passim; SYMONDS, "On the Application of Evolutionary Principles to Art and Literature", in SYMONDS, Essays, pp.27-52; Stephen HOULGATE, An Introduction to Hegel: Freedom, Truth and History, Oxford: Blackwell, 2005, pp.173-4. GREEN, Prolegomena, sections 5, 7, 84, 200, 251, $334,348$.

${ }^{96}$ SYMONDS, "Evolution", p.17; ibid., p.25n1.

${ }^{97}$ F.W.H. MYERS, “The Subliminal Consciousness", Proceedings of the Society for Psychical Research, 1892, 298-307; Symonds, Letters, vol.3, p.671; SCHULTZ, Sidgwick, pp.699-700.
} 
the process implied by self-culture and formation of habits is a lengthy one, and that the seductive process of living in sin with the hope of dying in grace is removed." 98

Eroticised fraternity is, then, a key facet in the evolution of the "Universal" or "Cosmic" Mind. Symonds' pantheism accords a central place to the physical expression of passion in the mystical intertwining of the Universe. In this way, Symonds' eroticised socialism is as much part of his effort to finally resolve the Victorian crisis of faith as it is to overcome the fragmentation of British society in the fin-de-siècle.

\section{Conclusion}

Symonds was a social heretic who physically removed himself and his family to Switzerland, as well as campaigning clandestinely with the constant possibility of exposure and consequent severe social and legal punishment. Yet, he sought also to develop a philosophical position that would enable the individual to overcome the personal angst that came with their frustrated need for self-expression. In his theories of culture, society and evolution, he sought to respect individual subjectivity while integrating his socially-deviant instinctive urges into an allencompassing social - and ultimately universal - whole. Intellectually, his ultimate goal was to overcome the tensions within his philosophical and practical project that were created by the invocation on personal sublimation, social and legal disobedience, and social reform.

Symonds's vision of the good society saw the embeddness of individuals within social structures as a precondition of the individual's self-effectuation - their personal development of a positive sense of personal identity. Their respective identities served to modify social forms sometimes radically - rather than merely to reproduce them. Symonds' socialism was the political expression of his sublimation of his sexual inversion. He was concerned to accommodate what were then socially-deviant subjectivities within an organic harmony of personalities that was particularised within a stable system of cultural norms and practices. In this sense, Symonds did not seek to develop a distinct social identity for those with unconventional proclivities, rather he wished them to enjoy the integrated existence of fullyactive and accepted citizens. Ultimately however, Symonds saw this as a vital part of the universal spiritual development, which he called the evolution of the Cosmic Mind. Symonds is significant for historians of social and political thought not least because his focus on deviant urges and personalities (but not his pantheistic absolutism) led him to anticipate the likes of Freud and Marcuse. Yet, it is vital to appreciate that underpinning Symonds' collectivist and

\footnotetext{
${ }^{98}$ SYMONDS, "Evolution", p.23.
} 
mystic reaction to the crisis-ridden late-Victorian Britain was what Gay has called the "essential elements of modernism - the lure of heresy and the cultivation of subjectivity."99

${ }^{99}$ GAY, Modernism, p.376. 